African Journal of Pharmacy and Pharmacology Vol. 5(9), pp. 1182-1189, 8 September, 2011

Available online http://www.academicjournals.org/ajpp

DOI: $10.5897 / A J P P 11.196$

ISSN 1996-0816 @2011 Academic Journals

Review

\title{
Resistin as a new molecule
}

\section{Iclal GEYIKLI ${ }^{1,3 *}$ and Muslum AKAN ${ }^{2,3}$}
${ }^{1}$ Department of Biochemistry and Clinical Biochemistry, Faculty of Medicine, Gaziantep University, Gaziantep 27310, Turkey.
${ }^{2}$ Department of Biochemistry, Graduate School of Health Science, Gaziantep University, Gaziantep 27310, Turkey. ${ }^{3}$ Department of Biochemistry and Clinical Biochemistry, School of Medicine, Gaziantep University, Şahinbey - Gaziantep - Turkey.

\section{Accepted 10 May, 2011}

\begin{abstract}
Adipose tissue, in addition to storing energy, secretes numerous factors implicated in modulating insulin, sensitivity and energy balance, such as leptin, adiponectin, TNF- $\alpha$ and resistin. Resistin, is a hormone that is produced by fatty cells, a recently described adipokine belonging to the cysteine-rich secretory protein family, was originally described as an adipocyte-derived polypeptide that links obesity and insulin resistance in mice. However, in humans, resistin is expressed at very low concentrations in adipose cells, but at high levels in mononuclear leukocytes, macrophages, spleen cells and bone marrow cells. In recent years, several studies have showed that resistin may play a role in cardiovascular disease, diabetes mellitus and also inflammation and process of inflammation related diseases. This review will summarize the results of studies related with resistin.
\end{abstract}

Key words: Adipose tissue, resistin, disease.

\section{INTRODUCTION}

Adipose tissue is increasingly recognized to be not only a storage organ for lipids but rather a metabolically highly active endocrine organ (Figure 1). Studies have revealed that adipocytes synthesize and secrete a number of biologically active molecules (Xiao-zhi et al., 2007), and adipose tissue regulates skeletal muscle insulin sensitivity through a number of cirlulating adipocytederived hormones (Gentile et al., 2008), so called adipcytokines, including tumor necrosis factor- $\alpha$ (TNF- $\alpha$ ), leptin, interleukin-6 (IL-6), plasminogen activator inhibitor1 (PAl-1), adiponectin, and resistin (Figure 2), which act locally and distally through autocrine, paracrine and endocrine effects (Table 1) (Kershaw and Flier, 2004; Takeishi et al., 2007; Xiao-zhi et al., 2007). It has become clear that the majority of these adipocyte-derived

${ }^{\star}$ Corresponding author. E-mail: Javadiiclalgeyikli@mynet.com, iclalgeyikli@hotmail.com. Tel: +903423606060/77785. Fax: +903423601617. hormones also have important vascular effects (Gentile et al., 2008). The autonomous nervous system acts directly on adipose tissue through its subdivisions, the sympathetic and parasympathetic systems. The sympathetic system promotes catabolic actions (lypolisis), through $\beta$-adrenergic stimulation, which activates the hormone-sensitive lipase enyzme (HSL). The parasympathetic system organizes anabolic actions by increasing insulin production and increasing glucose and fatty acid capture (Fonseca et al., 2007). In addition to these efferent signals, adipose tissue expresses numerous receptors that allow it to respond to afferent signals from traditional hormone systems as well as the central nervous system (Table 2) (Kershaw and Flier, 2004). Resistin was first presented by Steppan et al. (2001) as a novel peptide synthesized and secreted from murine adipocytes (Chu et al., 2008). Resistin is described, low-molecular weight $(12.5 \mathrm{kDa})$, adipokine that is a member of a cysteine-rich secretory protein family (Almehed et al., 2008; Bokarewa et al., 2005), known as resistin-like molecules (RELMs). 


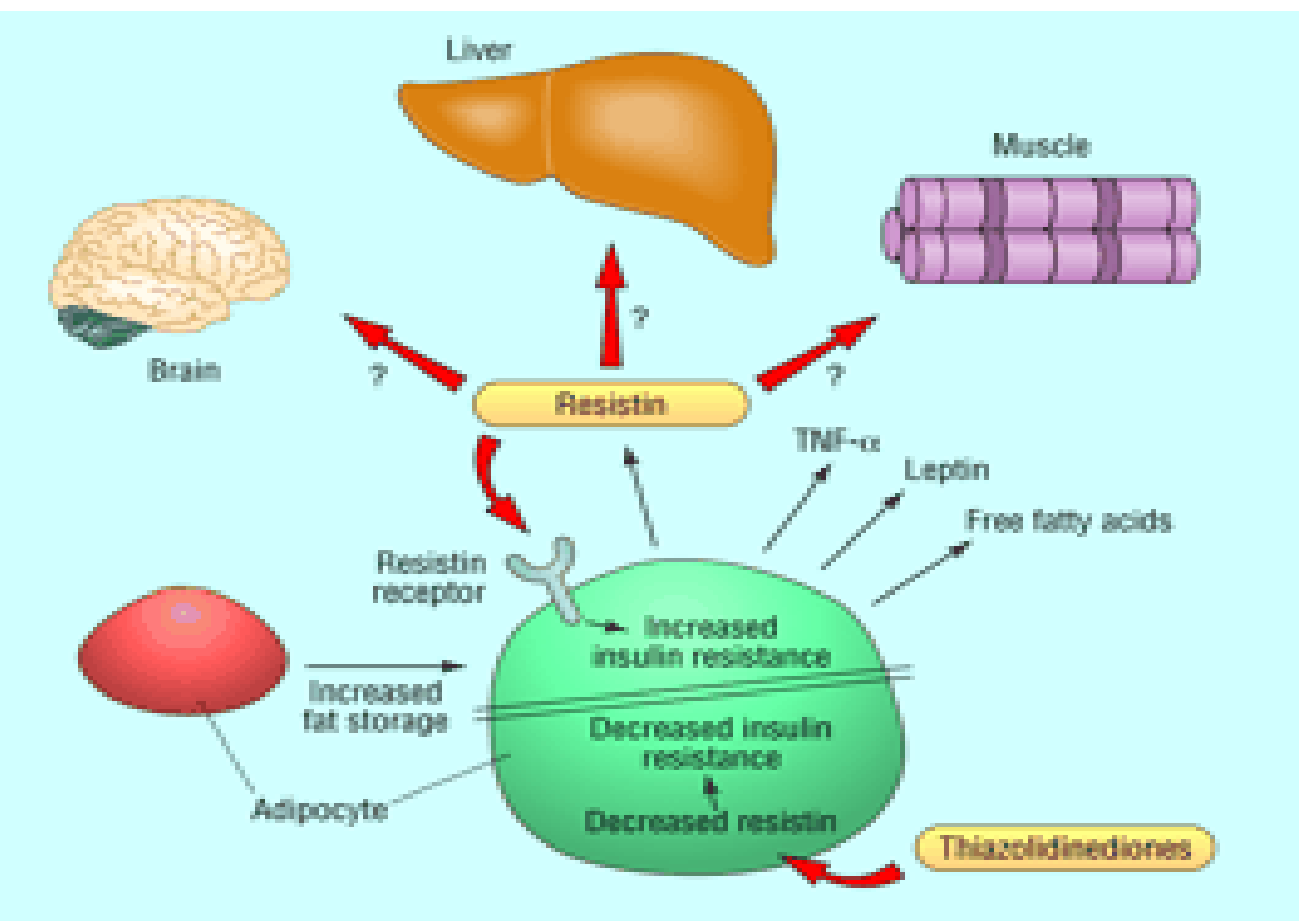

Figure 1. As fat cells (adipocytes) store more fat molecules, they release several products that can modify the body's sensitivity to insulin, such as free fatty acids and tumour necrosis factor a (TNFa), which cause insulin resistance. A newly identified protein, resistin, which is secreted by adipocytes, causes insulin resistance. Thiazolidinedione drugs, which are used to treat type 2 diabetes, may work through suppressing the expression of resistin by adipocytes (Berger, 2001).

\section{Pro-hyperglycaemic}

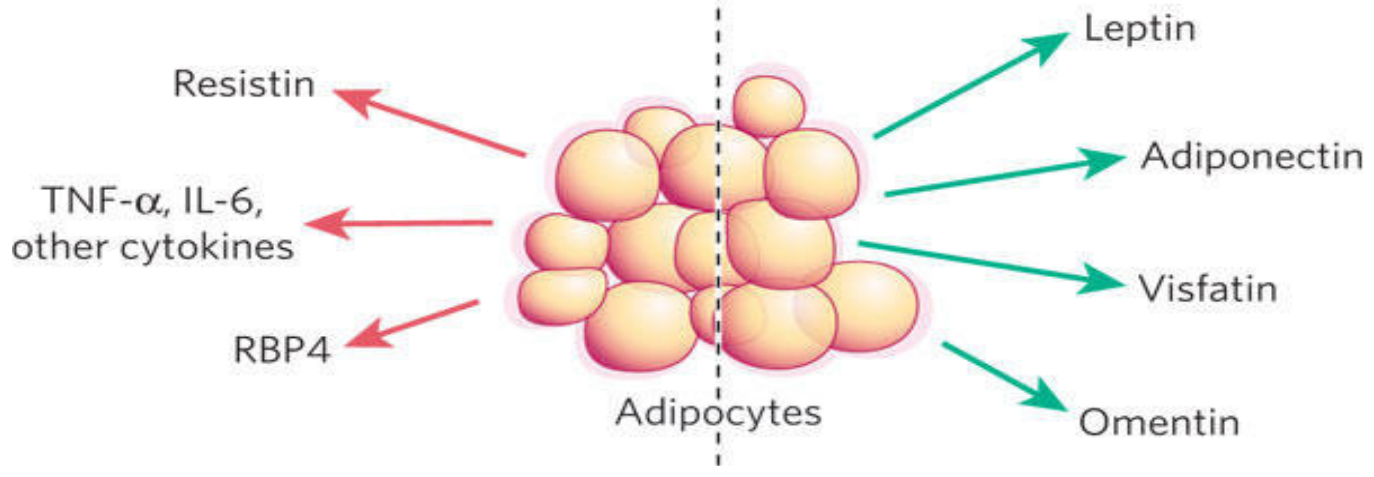

Figure 2. Adipocytes secrete proteins with varied effects on glucose homeostasis. Adipocyte-derived proteins with anti-diabetic action (green arrows) include leptin, adiponectin, omentin and visfatin. Other factors tend to raise blood glucose (red arrows), including resistin, TNF- $\alpha$ and RBP4. TNF- $\alpha$ and human resistin are probably secreted by non-adipocytes within the fat pad. IL, interleukin (Rosen and Spiegelman, 2006).

The family is characterized by a highly conserved, cysteine-rich $\mathrm{C}$ terminus in which the spacing of cysteines is invariant. There are four members in the mouse RELMs family: resistin, RELMa, RELM $\beta$, and 
Table 1. Examples of adipocyte-derived proteins with endocrine functions (Kershaw and Flier, 2004).

\begin{tabular}{|c|c|}
\hline \multirow{3}{*}{ Cytokines and cytokine-related proteins } & Leptin \\
\hline & TNF- $\alpha$ (Tumor necrosis factor $-\alpha)$ \\
\hline & IL-6 (Interleukin-6) \\
\hline Other immune-related proteins & MCP-1 (Macrophages and monoctye chemoattractant protein -1 ) \\
\hline Proteins involved in the fibrinolvtic svstem & PAI-1 (Plasminogen activator inhibitor - 1 ) \\
\hline 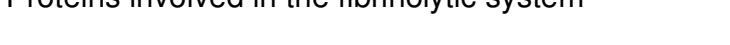 & Tissue factor \\
\hline \multirow{4}{*}{ Complement and complement-related proteins } & Adipsin (complement factor D) \\
\hline & Complement factor B \\
\hline & ASP (Adipsin and acylation stimulating protein) \\
\hline & Adiponectin \\
\hline \multirow{4}{*}{ Lipids and proteins for lipid metabolism or transport } & Lipoprotein lipase (LPL) \\
\hline & Cholesterol ester transfer protein (CETP) \\
\hline & Apolipoprotein $\mathrm{E}$ \\
\hline & NEFAs \\
\hline \multirow{3}{*}{ Enzymes involved in steroid metabolism } & Cytochrome P450-dependent aromatase \\
\hline & $17-\beta H S D$ \\
\hline & 11-ßHSD1 \\
\hline Other proteins & Resistin \\
\hline
\end{tabular}

Table 2. Examples of receptors expressed in adipose tissue (4).

\begin{tabular}{ll} 
& Insulin receptor \\
& Glucagon receptor \\
& GH receptor \\
Receptors for traditional endocrine hormones & TSH receptor \\
& Gastrin/CCK-B receptor \\
& Glucagon like peptide-1 receptor \\
& Angiotensin II receptors type 1 and 2 \\
& \\
& Glucocorticoid receptor \\
& Vitamin D receptor \\
& Thyroid hormone receptor \\
& Androgen receptor \\
& Estrogen receptor \\
& Progesterone receptor \\
& \\
Nuclear hormone receptors & Leptin receptor \\
IL- 6 receptor (Interleukin-6) & TNF- $\alpha$ receptor (Tumor necrosis factor $-\alpha)$ \\
& $\beta 1, \beta 2, \beta 3$, receptors \\
Catecholamine receptors & $\alpha 1, \alpha 2$, receptors \\
\hline
\end{tabular}


A

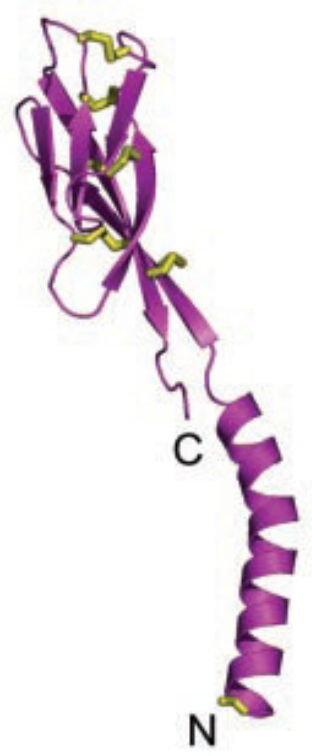

B
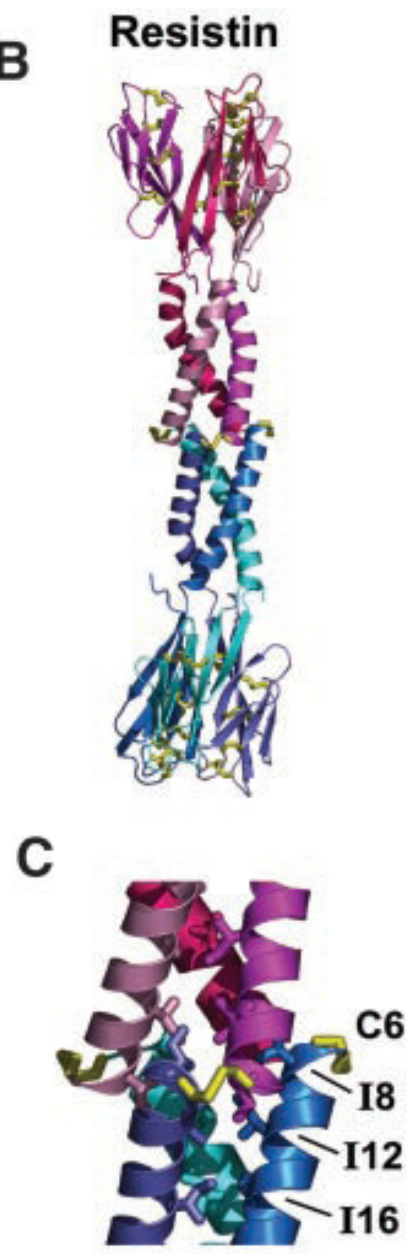

\section{RELM $\beta$}

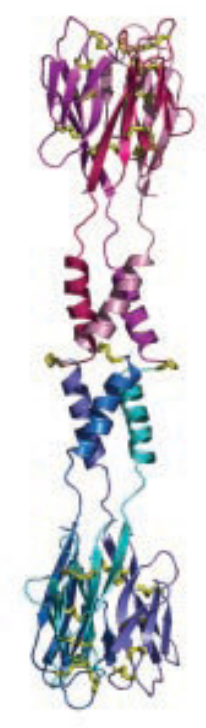

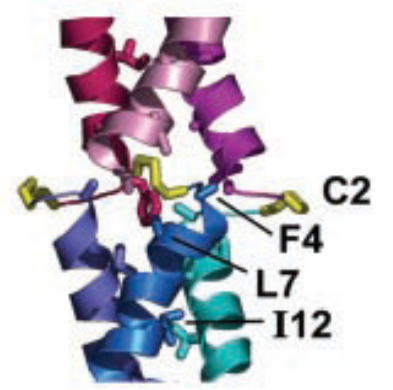

Figure 3. Ribbon diagram representations of resistin and RELM $\beta$. (A) A single resistin protomer molecule A from the C2221 crystal form depicts the architecture of resistin family proteins which are composed of a carboxyterminal disulfide-rich globular domain and an amino-terminal-helical region. (B) These protomers assemble to form trimer-dimer hexamers shown for both resistin and RELM $\beta$. In both structures each protomer from one trimer is disulfide linked to a protomer from the associated trimer. $(C)$ An expanded view of the trimer-dimer interface region depicts the surfaceexposed disulfide bonds (Cys6 and Cys2 in resistin and RELM $\beta$ respectively) and the short sixhelix bundle formed between the upper and lower trimers. Disulfide bonds are drawn in yellow. Molecular structure figures are drawn with the program PyMOL (Patel et al., 2004).

RELMy. Only two counterparts were found in human: resistin and RELM $\beta$ (Figure 3) (Degawa et al., 2003). Mouse resistin gene is localized to chromosome 8 and human resistin gene to chromosome 19. Mouse and human resistin share $64.4 \%$ sequence homology at mRNA level and $59 \%$ identity at the amino acid level. Mouse resistin is a 108 amino acid peptide with a molecular weight of $12.5 \mathrm{kDa}$. Whereas, human resistin mRNA encodes a 114 amino acid polypeptide containing a 20 amino acid signal sequence (Degawa et al., 2003; Krassas et al., 2005). Mouse resistin is almost exclusively expressed in white adipose tissue with high level, whereas human resistin expressed in adipose tissue is significantly lower, even undetectable under some conditions (Pang and Le, 2006). Resistin was originally named by Steppan et al. (2001) for its resistance to insulin [resist + in(sulin)] (Krassas et al., 2005). The discovery of resistin has directed intense research to fatderived mediators in obesity-induced insulin resitance and type 2 diabetes (Xiao-zhi et al., 2007). Resistin was reported to be secreted by adipocytes and to cause insulin resistance in animal models, which fueled the 
hypothesis that this hormone may play a role in the pathogenesis of obesity-mediated insulin resistance and diabetes. However, structure and biology of resistin differ substantially between species, and many aspects, specifically its association with obesity and its effects on insulin sensitivity in humans, remain controversial. In contrast to mice, human resistin is expressed at lower levels in adipocytes but at higher levels in circulating blood monocytes. In vitro, resistin activated human endothelial cells, leading to increased expression of adhesion molecules, and induced human aortic muscle cell proliferation (Weikert et al., 2008).

Circulating resistin level was increased in diet-induced and genetic froms of obesity but could be decreased using rosiglitazone therapy (Chu et al., 2008). During a search for adipocyte targets of thiazolidinediones, a class of insulin sensitizers, Steppan et al. (2001) discovered a novel adipocyte-derived hormone called resistin, which was suppressed by thiazolidinedione treatment (Gentile et al., 2008). It is also known as adipocyte-specific secretory factor (Almehed et al., 2008). The principal representatives of family are: 1 ) RELM- $\alpha$ (also known as FIZZ1 "found in inflammatory zone" or bronchoalveolar exudate triggered by allergic processes; 2$)$ RELM- $\beta$ (FIZZ2), which is abundantly expressed, especially in tumors of the colon, being related to the process of tumorigenesis; 3) resistin (FIZZ3) described in adipose tissue. Because of their cysteine-rich segment, resistin and RELM- $\beta$ dimerize, forming homo or heterodimers (Degawa et al., 2003; Fonseca et al., 2007). Resistin is expressed at very low levels, if at all, in human adipose cells, with the greatest concentrations in female gonadal adipose tissue. Whereas high levels are expressed in inflammatory cells that are mononuclear leukocytes and macrophages, spleen, and bone marrow cells (Almehed et al., 2008; Bokarewa et al., 2005; Krassas et al., 2005). Low levels of resistin are also expressed in lung tissue, resting endothelial cells, and in human placenta (Bokarewa et al., 2005; Yura et al., 2003).

\section{The effects of personal factors on resistin levels}

Gerber et al. (2005) have investigated serum resistin levels of obese and lean children and adolescents in 2005. Their aim was to hypothesize that resistin links obesity with diabetes, but this has not been studied in children and adolescents to date. They determined serum resistin levels of 135 obese (body mass index, 32.0 \pm 6.2 $\mathrm{kg} / \mathrm{m}^{2}$;age, $12.6 \pm 3.4$ year) and 201 lean children (body mass index, $18.7 \pm 2.4 \mathrm{~kg} / \mathrm{m}^{2}$; age, $12.5 \pm 2.5$ year). They found that resistin levels were significantly higher in girls than in boys in obese children group and control group of lean children. Besides, There were no differences between obese and lean chlidren for gender and age. Resistin levels of whole group correlated with Tanner puberty stage and age (Gerber et al., 2005). In a investigation about the serum resistin levels in critically ill patients was researched by RWTH-University Hospital Aachen in Germany. About 170 patients (122 with sepsis, 48 without sepsis) were studied prospectively and compared with 60 healthy non-diabetic controls. Alexander and et al. have found that serum resistin concentrations were significantly elevated in all critical care patients compared with healthy controls, significantly higher in sepsis than in non-sepsis patients. Serum resistin concentrations were not associated with preexisting type 2 diabetes or obesity that patients with body mass index greater than 30 in the sepsis and non-sepsis cohort (Koch et al., 2009). When resistin levels were measured in 126 patients with congestive heart failure and 18 control subjects.

The normal upper limit of resistin level was defined as mean +2 SD value, and for 18 control subjects, it was $14.1 \mathrm{ng} / \mathrm{ml}$. There were 32 patients with a high resistin level $(>14.1 \mathrm{ng} / \mathrm{ml})$ and 94 patients with a low resistin level $(\leq 14.1 \mathrm{ng} / \mathrm{ml})$. Serum resistin levels were found that not correlated with body mass index (Takeishi et al., 2007).

In another study, Serum resistin levels have defined in type 2 diabetes mellitus and coronary heart disease. At the same time, serum resistin levels were significantly higher in type 2 diabetes mellitus $22.6 \pm 4.5 \mathrm{ng} / \mathrm{ml}$ and coronary heart disease $24.2 \pm 3.6 \mathrm{ng} / \mathrm{ml}$ compared with case controls $18.9 \pm 3.4 \mathrm{ng} / \mathrm{ml}$ (Al-Daghri et al., 2005). As compare resistin levels in serum or follicular fluid from women with polycystic ovarian syndrome (PCOS) and controls, both of whom were undergoing in vitro fertilization (IVF). In Seow et al. (2004) and have found that there was no significant difference in either serum or follicular resistin levels between the control group and PCOS group. However, resistin levels in serum were higher than in follicular fluid in both group that were the POCS and control groups. Multiple regression analysis have showed that resistin levels did not correlate with body mass index (Xiu-e et al., 2005; Seow et al., 2005).

\section{Alterations of resistin levels in any case}

To has an objective of the study was to assess the relationship between circulating resistin levels and insulin sensitivity in gestational diabetes mellitus (GDM). In total, 58 Caucasian women with a singleton pregnancy who had been referred for a $100 \mathrm{gr}$ oral glucose tolerance test were enrolled between the weeks 26 and 30 , and 22 women with GDM were also evaluated after pregnancy. Serum resistin and insulin sensitivity have measured in 
GDM during and after pregnancy. The relationship of resistin to metabolic abnormalities was evaluated. Resistin levels were lower in GDM women than in pregnant women with normal glucose tolerance $(4.32 \pm 1.56 \mathrm{ng} / \mathrm{ml}$ vs $9.30 \pm 1.32 \mathrm{ng} / \mathrm{ml})$. In the subset of women with GDM, no significant differences were observed between the group treated with nutrition therapy and those with additional insulin therapy $(4.59 \pm 1.47$ vs $4.00 \pm 1.70 \mathrm{ng} / \mathrm{ml})$. In this study, lower resistin levels in GDM women compared with normal glucose tolerance women during pregnancy and a decrease in resistin levels in the postpartum period in the GDM group (Megia et al., 2008).

\section{METHODS}

In a study, resistin levels were detected with a sandwich enzyme-linked immonosorbent assay (ELISA). Briefly, samples diluted $1: 10$ with $1 \%$ bovine serum albumin phosphate-buffered saline were introduced into the paralel strips coated with capture polyclonal anti-resistin antibodies. Biotin-labelled anti-resistin antibodies, streptavidin-horseradish peroxidase conjugate, and corresponding substrate were used for color development. The obtained absorbance values were compared with the serial dilution of recombinant human resistin. The lowest detectable level was $31 \mathrm{ng} / \mathrm{ml}$ (Chu et al., 2008). In another study of about resistin measurement, serum or plasma resistin concentrations also were measured by using ELISA that was to be commercially test kits (Heidemann et al., 2008; Norata et al., 2007; Seow et al., 2005; Takeishi et al., 2007). Blood samples for resistin almost obtained at admission for measurement of serum levels of resistin were drawn and centrifuged at $2,500 \mathrm{G}$ for $15 \mathrm{~min}$ at $4^{\circ} \mathrm{C}$ within $30 \mathrm{~min}$ of collection, and the serum obtained was stored at $-70^{\circ} \mathrm{C}$ or $-80^{\circ} \mathrm{C}$ until analysis (Takeishi et al., 2007; Zou et al., 2007). In most studies, the unit of measurement used was $\mathrm{ng} / \mathrm{ml}$, though some used $\mu \mathrm{g} / \mathrm{L}$ in other studies (Bo et al., 2007, Takeishi et al., 2007; Yalçindağ et al., 2008). Zao et al. (2007) carried out a study on 37 non-obese children without other endocrine, metabolic or kidney disease, including 17 boys and 20 girls aged from 7.3 to 14.9 years (mean $10.3 \pm 1.8$ years). They investigated relationship between insulin resistance and serum levels of resistin, and found that the mean resistin levels were $4.25(2.06$ to 10.25$) \mu \mathrm{g} / \mathrm{L}$. Serum resistin levels have revealed $13.0 \pm 6.9 \mathrm{ng} / \mathrm{ml}$ in 19 healthy subjects (10 male and 9 female) that mean age was $33.9 \pm 7$ (Yalçindağ et al., 2008).

In another study, serum resistin levels were $8.71 \mathrm{ng} / \mathrm{ml}$ (6.58 to $11.56 \mathrm{ng} / \mathrm{ml}$ ) in 31 subjects who were scheduled for coronary angiography but did not fulfill angiographic criteria nor coronary artery disease and no coronary spasm. Their mean age was $55.4 \pm 7.6 ; 61.3 \%$ male and $38.7 \%$ female (Wen-lan et al., 2007). Serum resistin concentrations were found as $20.3 \pm 10.0 \mathrm{ng} / \mathrm{ml}$ in older persons that were aged, $73.6 \pm 2.9$ years; $48.1 \%$ men; $58.8 \%$ white (Butler et al., 2009).

\section{Effect of drugs on resistin levels}

Ohbayashi has investigated patients with hypercholesterolemia. Ohbayasahi's studies aim was to research whether pitavastatin can regulate the serum level of resistin, together with levels of other inflammatory cytokines and adipocytokines. In his study, forty-two outpatients (mean age $65.2 \pm 12.2$ year, male/female: 21/21) with hypercholesterolemia were administered 2 $\mathrm{mg}$ of pitavastatin and serum levels of resistin were measured before and 12 week after enrollment. Pitavastatin significantly has reduced serum resistin levels from $17.1 \pm 9.9$ to $15.2 \pm 10.0 \mathrm{ng} / \mathrm{ml}$ following 12 weeks of therapy, which did not significantly correlate with a decrease in total cholesterol and LDL-cholesterol levels. Therefore, this reduction can be regarded as an important pleiotropic effect of pitavastatin to prevent the progression of atherosclerosis (Ohbayashi, 2008). Krassas et al. (2005) have investigated resistin levels in hyperthyroid patients before and after restoration of thyroid function: relationship with body weight and body composition. In their study, a total of 43 hyperthyroid patients (12 men and 31 women) were investigated, in addition to 23 controls. Anthropometric parameters and resistin concentrations were measured. All the patients commenced taking antithyroid drugs and 3 to 4 months later the same investigations were performed in 36 of the 43 individuals. They have found that the hyperthyroid patients exhibited increased resistin concentrations in comparison with controls. Normalization of thyroid hormones was accompanied by a significant decrease in resistin concentrations. A sex difference was also found, men showing a significant decrease in resistin concentration, whereas in women no such difference was found.

Resistin concentrations did not correlate with different anthropometric parameters, age and thyroid hormones, either before or after treatment. As a result, resistin concentrations were increased in hyperthyroidism, they were not associated with body weight, body fat, waist circumference or BMI, which makes it unlikely that resistin plays a crucial part in thermogenesis and energy homeostasis in thyrotoxic patients (Krassas et al., 2005).

\section{The relation of resistin levels with diseases}

Reilly et al. (2005) have presented the first large study in 
human to examine whether plasma levels are associated with metabolic and inflammatory markers, as well as with coronary artery calcification (CAC), a quantitive index of atherosclerosis, in 879 asymptomatic subjects in the study of inherited risk of atherosclerosis. Resistin levels were associated with increasing CAC after adjustment for age, sex, and established risk factors and further control for metabolic syndrome and plasma C-reactive protein (CRP) levels. In subjects with metabolic syndrome, resistin levels further predicted CAC, whereas CRP levels did not. They have found that plasma resistin levels are correlated with markers of inflammation and are predictive of coronary atherosclerosis in humans, independent of CRP and resistin might represent a novel link between metabolic signals, inflammation and atherosclerosis (Reilly et al., 2005). One study published in 2005 compared serum resistin levels with CRP and LDL-cholesterol in type 2 diabetes and coronary artery disease in Saudi population. Al-Daghri et al. (2005) have found that serum resistin levels were 1.2-fold higher in type 2 diabetes and 1.3-fold higher in coronary heart disease than in controls. In addition, CRP was significantly increased in both type 2 diabetes and coronary heart disease patients. The findings from this study further implicated resistin as a circulating protein associated with type 2 diabetes mellitus and coronary heart disease and this also demonstrated an association between resistin and CRP, a marker of inflammation in type 2 diabetic patients (Al-Daghri et al., 2005). A study of Wen-lan et al. (2007) about the plasma resistin and in patients with unstable angina. Their study have demonstrated that plasma resistin concentrations increased in patients with coronary artery disease, and they were signidicantly higher in patients with unstable angina compared with stable angina. This confirmed that resistin concentrations were associated with systemic inflammation (Wen-lan et al., 2007). In an other study Chu et al; 2008 have investigated plasma resistin levels association with myocardium injury in patients with acute coronary syndrome. Their investigation have occured the 39 patients with acute coroanry syndrome (ACS) and 26 age-healthy subjects. They found that plasma resistin levels were significantly increased in patients with ACS at $24 \mathrm{~h}$ after symptoms onset and remained at a high level for 1 week, and were significantly higher in patients with acute myocardial infarction than in those with unstable angina.

In addition, plasma resistin level was correlated positively with peak plasma creatine kinase (CK), the MB isoform of CK and Troponin I, and was correlated negatively with left ventricular ejection fraction. No correlation was found between plasma resistin with level of metabolic parameters or inflammatory markers (Chu et al., 2008). Takeishi et al. (2007) have investigated between 2001 and 2004, serum resistin levels with high risk in patients with congestive heart failure. The patients were followed up with end-points of cardiac death and rehospitalization caused by worsening of heart failure. They found that the serum resistin levels were higher in patients with heart failure than in control subjects and were not correlated with body mass index or blood glucose (Takeishi et al., 2007). On et al. (2007) have investigated serum resistin as a biological marker for coronary artery disease and restenosis in type 2 diabetic patients. The study was included 45 diabetic patients with coronary artery disease (DMCAD) and 47 diabetus mellitus controls (DM). In this study, serum resistin concentrations were higher in the DMCAD group than in the controls and had no correlations with weight, body mass index (BMI), waist circumference, blood pressure but only the HOMA-IR significantly correlated with serum resistin concentration. Results have shown resistin might proved to be a useful biological marker for coronary artery disease and restenosis in patients with type 2 diabetus mellitus (On et al., 2007). The objective of the study that was investigated the association between plasma resistin levels and risk of future myocardial infraction (MI) and ischemic stroke (IS) in a large prospective cohort. Weikert et al. (2008) found that after multivariable adjustment for established cardiovascular risk factors including $\mathrm{C}$-reactive protein, individuals in the highest compared with the lowest quartile of plasma resistin levels had a significantly increased risk of myocardial infraction. In contrast, plasma resistin levels were not significantly associated with risk of ischemic stroke (Weikert et al., 2008).

In the Department of Rheumatology, 163 female patients with systemic lupus erythematosus (SLE) (20 to 82 years old) were examined in a cross-sectional study. Serum resistin levels in controls were similar to those of patients with SLE. Markers of inflammation (erythrocyte sedimentation rate (ESR), C-reactive protein) and current dose of glucocorticosteroids correlated positively to resistin in serum. Markers of renal function (creatine) and bone mineral density were significantly associated with resistin. Although resistin measurements did not differ between patients and controls, resistin was clearly associated with general inflammation, renal disease, treatment with glucocorticosteroids, and bone loss (Almehed et al., 2008).

\section{RESULTS}

Most studies have shown that serum or plasma resistin levels are significantly higher in girls or women than in boys or men. Resistin levels almost did not correlate with body mass index in the multiple regression analyses. 
Resistin concentrations generally have measured by using ELISA that to be commercially kits. It was required more studies that showing effect of drugs on resistin concentrations. It has association with obesity, diabetes and coronary artery disease and so on, but these studies should repeated in another area. Then resistin can be a useful marker for the disease's diagnosis.

\section{ACKNOWLEDGEMENT}

We would like to thank Ece MERAM from Koç University for critical reading this manuscript.

\section{REFERENCES}

Al-Daghri N, Chetty R, McTernan PG, Al-Rubean K, Al-Attas O, Jones AF (2005). Serum resistin is associated with C-reactive protein and LDL-cholestrol in type 2 diabetes and coronary artery disease in a Saudi population. Cardiovasc. Diabetol., 4(10): 1-6.

Almehed K, d'Elia HF, Bokarewa M, Carlsten H (2008). Role of resistin as a marker of inflammation in systemic lupus erythematosus. Arthritis Res. Ther., 10(1): 1-9.

Berger A (2001). Resistin: A new hormone that links obesity with type 2 diabetes. BMJ, 322(7280): 193.

Bo S, Ciccone G, Durazzo M, Gambino R, Massarenti P, Baldi I (2007). Efficacy of antioxidant treatment in reducing resistin serum levels: $A$ randomized study. Plos Clin. Trials, 2(5): 1-8.

Bokarewa M, Nagaev I, Dahlberg L, Smith U, Tarkowski A (2005). Resistin, an adipokine with proinflammatory properties. J. Immunol., 174: 5789-5795.

Butler J, Kalogeropoulos A, Georgiopoulou V, De Rekeneire N, Rodondi $\mathrm{N}$, Smith AL (2009). Serum resistin concentrations and risk of new onset heart failure in older persons: The health, aging, and body composition (Health ABC) study. Arterioscler. Thromb. Vasc. Biol., 29(7): 1149-1149.

Chu S, Ding W, Li K, Pang Y, Tang C (2008). Plasma resistin associated with myocardium injury in patients with acute coronary syndrome. Circ. J., 72: 1249-1253.

Degawa-Yamauchi M, Bovenkerk JE, Juliar BE, Watson W, Kerr K, Jones $R$ (2003). Serum resistin (FIZZ3) protein is increased in ebese humans. J. Clin. Endocrinol. Metab., 88(11): 5452-5455.

Fonseca-Alaniz MH, Takada J, Alonso-Vale MIC, Lima FB (2007). Adipose tissue as an endocrine organ: from theory to practice. J. Pediatr. (Rio J), 83(5): 192-203.

Gentile MT, Vecchione C, Marino G, Aretini A, De Pardo A, Antenucci G (2008). Resistin impairs insulin-evoked vasodilation. Diabetes, 57: 577-583.

Gerber M, Boettner A, Seidel B, Lammert A, Bar J, Schuster E (2005). Serum resistin levels of obese and lean children and adolescents: Biochemical analysis and clinical relevance. J. Clin. Endocrinol. Metab., 90: 4503-4509.

Heidemann C, Sun Q, VanDam RM, Meigs JB, Zhang C, Tworoger SS (2008). Total and high-molecular-weight adinopectin and resistin in relation to the risk for type 2 diabetes in woman. Ann. Int. Med., 149: 307-316.

Kershaw EE, Flier JS (2004). Adipose tissue as an endocrine organ. J. Clin. Endocrinol. Metab., 89(6): 2548-2556.

Koch A, Gressner OA, Sanson E, Tacke F, Trautwein C (2009). Serum resistin levels in critically ill patients are associated with inflammation, organ dysfunction and metabolism and may predict survival of nonseptic patients. Crit. Care Med., 13(3): 1-9.
Krassas GE, Pontikides N, Loustis K, Koliakos G, Constantinidis T, Panidis D (2005). Resistin levels in hyperthyroid patients before and after restoration of thyroid function: Relationship with body weight and body composition. Eur. J. Endocrinol., 153: 217-221.

Megia A, Vendrell J, Gutierrez C, Sabate M, Broch M, Fernandez-Real JM (2008). Insulin sensitivity and resistin levels in gestational diabetes mellitus and after parturition. Eur. J. Endocrinol., 158: 173178.

Norata GD, Ongari M, Garlaschelli K, Raselli S, Grigore L, Catapano AL (2007). Plasma resistin levels correlate with determinants of the metabolic syndrome. Eur. J. Endocrinol., 156: 279-284.

Ohbayashi H (2008). Pitavastatin improves serum resistin levels in patients with hypercholesterolemia. J. Atheroscler. Thromb., 15(2): 87-93.

On YK, Park HK, Hyon MS, Jeon ES (2007). Serum resistin as a biological marker for coronary artery disease and restenosis in type 2 diabetic patients. Circ. J., 71: 868-873.

Pang S, Le Y (2006). Role of resistin in inflammation and inflammationrelated diseases. Cell. Mol. Immunol., 3(1): 29-34.

Patel SD, Rajala MW, Rossetti L, Scherer RE, Shapiro L (2004). Disulfide-Dependent multimeric assembly of resistin family hormones. Science, 304: 29-33.

Reilly MP, Lehrke M, Wolfe ML, Rohatgi A, Lazar MA, Rader DJ (2005). Resistin is an inflammatory marker of atherosclerosis in humans. Circulation, 111: 932-939.

Rosen ED, Spiegelman BM (2006). Adipocytes as regulators of energy balance and glucose homeostasis. Nature, 444: 847-583.

Seow KM, Juan CC, Hsu YP, Ho LT, Wang YY, Hwang JL (2005). Serum and follicular resistin levels in women with polycystic ovarian syndrome during IVF-stimulated cycles. Hum. Reprod., 20(1): 117121.

Seow KM, Juan CC, Wu LY, Hsu YP, Yang WM, Tsai YL (2004). Serum and adipocyte resistin in polycystic ovary syndrome with insulin resistance. Hum. Reprod., 19 (7): 1681.

Steppan CM, Bailey ST, Bhat S, Brown EJ, Banerjee RR, Wright CM (2001). The hormone resistin links obesity to diabetes. Nature, 409(6818): 307-312.

Takeishi Y, Niizeki T, Arimoto T, Nozaki N, Hirono O, Nitobe J (2007). Serum resistin is associated with high risk in patients with congestive heart failure - A novel link between metabolic signals and heart failure. Circ. J., 71: 460-464.

Weikert C, Westphal S, Berger K, Dierkes J, Möhlig M, Spranger J (2008). Plasma resistin levels and risk of myocardial infarction and ischemic stroke. J. Clin. Endocrinol. Metab., 93(7): 2647-2653.

Wen-lan H, Shu-bin Q, Qing H, Jian-song $Y$ (2007). Plasma resistin is increased in patients with unstable angina. Chin. Med. J., pp. 871 875.

Xiao-zhi Q, Yun-mei Y, Zhe-rong X, Li-ai Y (2007). Relationship between resistin level in serum and acute coronary syndrome or stable angina pectoris. J. Zhejiang Sci. B.m., 8(12): 875-880.

Xiu-e L, He-feng H, Mei-gen L, Yi-min Z, Yu-li Q, Min-yue D (2005). Resistin levels of serum follicular fluid in non-obese patients with polycystic ovary syndrome during IVF cycles. J. Zhejiang Sci. B., 6(9): 897-902.

Yalçindağ FN, Yalçindağ A, Batioğlu F, Çağlayan O, Kisa Ü, Özdemir Ö (2008). Evaluation of serum resistin levels in patients with ocular and non-ocular Behçet's disease. Can. J. Ophthalmol., 43(4): 473-475.

Yura S, Sagawa N, Itoh H, Kakui K, Nuamah MA, Korita D (2003). Resistin is expressed in the human placenta. J. Clin. Endocrinol. Metab., 88(13): 1394-1397.

Zao CC, Liang L, Hong F (2007). Relationship between insulin resistance and serum levels of adiponectin and resistin with childhood obesity. Indian Pediatr., 44: 275-279. 